\title{
Ideologiczne zawłaszczenia i kulturowe wywłaszczenia. Centesimus annus a teoria krytyczna
}

W popularnych czy nawet słownikowych opracowaniach współczesnej teologii katolickiej, szerzej - nauczania kościelnego, także jego społecznych aspektów, stosunkowo niewiele miejsca poświęca się teorii krytycznej. Owszem, odnajdziemy tam rozrzucone nawiązania do poszczególnych idei czy postaci powiązanych z tym nurtem myślowym ze strony akademików, pozostających w bliskości z chrześcijańską myślą teologiczną czy społeczną ${ }^{1}$. Dość znaczącym rezonansem odbiło się spotkanie i dialog, jaki wywiązał się między kardynałem Josephem Ratzingerem a Jürgenem Habermasem ${ }^{2}$. To przecież jeden z czołowych luminarzy drugiej fazy rozwojowej szkoły frankfurckiej, która stanowi istotny etap i komponent intelektualny w rozwoju teorii krytycznej. Obserwacja generacyjnego oraz ideowego zróżnicowania, a także trans-

${ }^{1}$ Np. teologia polityczna Johanna-Baptista Metza, do pewnego stopnia teologia krytyczna Charlesa Davisa. Elementy teorii komunikacji Jürgena Habermasa aplikuje do teologii trynitarnej Markus Knapp. W Polsce wypowiada się Tadeusz Guz.

2 Kardynał Joseph Ratzinger spotkał się z Jürgenem Habermasem 19 stycznia 2004 r. w Akademii Katolickiej w Monachium. Podstawowym przedmiotem dyskusji uczyniono problem idei europejskiej, miejsce religii w społeczeństwie, problem postsekularyzacji oraz relacji rozumu z wiarą religijną. Fragmenty polskiego tłumaczenia można znaleźć w „Tygodniku Powszechnym” 18 (2005). Na marginesie tego spotkania pojawiła się kontynuacja dialogu z katolickimi akademikami z Jezuickiej Szkoły Filozoficznej z Monachium, co zaznaczono we wstępie - J. Habermas i in., An awereness of what is missing. Faith and reason in a post-secular age, trans. C. Cronin, Cambridge 2010, s. viI. Por. M. Junker-Kenny, Habermas and theology, London-New York 2011; Habermas and religion, eds. C. Calhoun, E. Mendieta, J. Van Antwerpen, Cambridge 2013. Teksty szkoły frankfurckiej o religii zebrał Eduardo Mendieta, The Frankfurt School on religion. Key writings by the major thinkers, London-New York 2005. 
formacji, jakim ulegało to środowisko, jedynie pogłębia wrażenie, iż ze strony chrześcijańskiej mamy do czynienia z proporcjonalnym brakiem zainteresowania. Jego występowanie może dziwić z co najmniej dwóch powodów. Pierwszy, nazwijmy go umownie zewnętrznym (wobec nauczania katolickiego), daje się uzasadnić faktem, iż teoria krytyczna to niezmiernie wpływowy nurt myślowy skupiony wokół znaczących postaci XX-wiecznej filozofii oraz obejmujący swymi zainteresowaniami dość szerokie spektrum zagadnień i problemów, jakimi tętni nasza współczesność. $\mathrm{W}$ jego obrębie odnajdziemy odniesienia do polityki, historii, literatury, pedagogiki, komunikacji społecznej, religii, estetyki czy kwestii moralnych. Druga racja usprawiedliwiająca potrzebę podjęcia dyskusji wyrasta $\mathrm{z}$ wnętrza samego katolicyzmu, który przecież, również w obrębie refleksji społeczno-politycznej, szerzej - kulturowej, zawierał i wciąż podnosi elementy diagnozy oraz postulaty przemian, współbrzmiących z ideami czy intelektualnymi troskami bliskimi teorii krytycznej. Oczywiście rzeczona symilarność, wyrażająca się chociażby w dystansie wobec iluzji zawartych w oświeceniowych obietnicach współczesności, odkrywaniu granic sekularyzacji, czy zbieżne oceny dotyczące negatywnych zjawisk, jakie wyrastają z kapitalizmu bądź (po)nowoczesności, posiadają swoje wyraźne ograniczenia, których nie sposób wymazać.

Encyklika Centesimus annus zdaje się potwierdzać, zaznaczone powyżej, zjawisko pomijania. Dokonując jej lektury, nie odnajdziemy nawiązań do autorów z kręgu teorii krytycznej. Tym samym można byłoby przypuszczać, iż szukanie nawet odległych konwergencji jawi się jako czynność jałowa lub nawet nadużycie. Jednocześnie wielokrotnie podkreślano, iż specyfika nauczania papieża Wojtyły polegała na głębszym zakorzenieniu w myśleniu filozoficznym. Owo zakorzenienie stanowi ogólniejszy rys patrzenia na analizowane problemy, odnajduje odzwierciedlenie w sposobie ich podejmowania, wkracza w treść eksplikacji nauczania kościelnego, a także dotyka warstwy argumentacyjnej. Nie inaczej mają się sprawy z Centesimus annus. Wydaje się, że filozoficzna, ale też metodologiczna perspektywa, która umożliwi odnalezienie równie skromnego, co znaczącego pomostu dyskusji z teorią krytyczną, znajduje się w sytuowaniu oraz wyjaśnianiu relacji zachodzącej między filozofią a ideologią. „Ufilozoficznienie” papieskiego nauczania wskazywałoby, iż ta przedteologiczna warstwa dyskusji nie tylko przygotowuje analizy specyfikujące teologiczny punkt widzenia, lecz „wchodząc wewnątrz” 
teologii, integralnie współbrzmi z jej rozważaniami. Związki między filozofią a ideologią przewijają się w papieskim dokumencie i choć zdają się być podjęte marginalnie, to jednocześnie są obecne jako jeden z centralnych elementów matrycy myślowej, jaką się operuje. Zagadnienie ideologii, jej krytyki jawi się więc jako racja uzasadniająca oraz platforma rozmowy z teorią krytyczną.

\section{Kontekst}

Centesimus annus to przede wszystkim dokument nawiązujący do nauczania społecznego papieży i Kościoła, odwołujący się wprost do „historycznej" (w relacji do czasu i nade wszystko rangi) encykliki przygotowanej oraz promulgowanej przez Leona XIII. Nawiązanie dokonane przez Jana Pawła II sięga do analogii „rzeczy nowych” naszych czasów, to znaczy zachęca do zmierzenia się z podobnymi wyzwaniami, przed jakimi stanęła ludzkość oraz Kościół równo sto lat wcześniej. To, co „nowe”, krzyżuje się ze „starym” w paradoksalnej cyrkulacji, gdyż uwagi poczynione w Rerum novarum nie straciły na aktualności, wręcz przeciwnie przewidywania Leona XIII „urzeczywistniły się”. Oto żywo dyskutowane w XIX wieku zagadnienia związane, $\mathrm{w}$ pewnym uproszczeniu, $\mathrm{z}$ „kwestią robotniczą" zostają skonfrontowane w nowym otoczeniu, w zmienionym kontekście historycznym oraz społeczno-politycznym. Komunizm, nie bez ideowej i politycznej kontry wobec chrześcijaństwa, prezentował się jako najlepszy adwokat „sprawy robotniczej”, ale składane obietnice oraz instytucjonalno-ekonomiczne instrumenty do ich realizacji okazały się całkowicie błędne. Symboliczną cezurą zmian czyni się rok 1989. Wiąże się z tą datą wyraźne symptomy wskazujące na ostateczne fiasko systemu realnego komunizmu. Dobitnym potwierdzeniem tego faktu okazał się rozpad Związku Sowieckiego, będącego polityczną inkarnacją komunizmu, oraz upadek sowieckiej dominacji w krajach należących do tzw. bloku wschodniego. I choć analogiczne procesy zaszły też w innych kręgach geograficznych, od Ameryki Łacińskiej po Afrykę i Azję̧, to czynnymi świadkami komunistycznej klęski byli polscy robotnicy

3 CA 12.

4 Zob. CA 22. 
zorganizowani „w imię solidarności”. Zaakcentowane w tekście polskie doświadczenie „Solidarności” nabiera cech doświadczenia uniwersalnego, stanowiąc kontrapunkt wobec komunistycznej odpowiedzi na rozwiązanie „kwestii robotniczej”' ${ }^{\prime \prime}$ Na ruinach marksistowskiej utopii, ale też patrząc wstecz na tekst wielkiego poprzednika Leona XıII, co podkreśla Jan Paweł II, dokładniej dostrzegamy celność chrześcijańskiej refleksji o polityce i gospodarce, własności i pracy, wolności i zniewoleniu, dobru i złu. Przypomnienie chrześcijańskich racji nie może oznaczać uśpienia. Wręcz przeciwnie. Papież daleki jest od ogłoszonej niewiele lat później hipotezy o „końcu historii”. „Nowe rzeczy” naszych czasów, jakie wyłoniły się na gruzach $\mathrm{xx}$-wiecznych totalitaryzmów, także w wersji marksistowsko-leninowskiej, zachęcają raczej do intelektualnej czujności niż uśpienia. Chodzi o to, że klęska realnego komunizmu jest tylko jedną z odsłon „nowych czasów”, w jakiej znalazła się ludzkość oraz Kościół. Druga odsłona wiąże się z demokratycznym systemem politycznym. Demokracja posiada niewątpliwe atuty, które przecież umożliwiły pokonanie niezwykle groźnego adwersarza, ale nie oznacza to, iż Kościół i jego nauczanie identyfikują się z określonym systemem politycznym. Podobne utożsamienie prowadziłoby do zaprzeczenia religijnej misji, ku jakiej Kościół został powołany, oraz pozbawiało prawa do wyrażania krytycznego dystansu, motywowanego transcendentnym celem tej misji. W sytuacji światowej, gdzie następuje rozpowszechnienie polityki demokracji, powstają nowe wyzwania. Nie chodzi już tylko o konieczność zmierzenia się z dotychczasowymi trudnościami, które zostały źle zdiagnozowane przez marksizm i wciąż czekają na rozwiązanie poza marksistowską kalką (np. bieda, alienacja, praca, marginalizacja, konsumpcjonizm $)^{7}$. Powstaje ryzyko, że w obrębie demokratycznych obietnic mogą się pojawić i pojawiają się „nowe rzeczy”, które tworzą otwarty horyzont tego, co dla osoby ludzkiej i samego Kościoła będzie stanowić świat wyzwań wyłaniających się z "nowych czasów”. Jak też możemy wyczytać z papieskich wskazań zamieszonych w końcowych fragmentach Centesimus annus, pola konfrontacyjne będą się wiązały z płaszczyzną

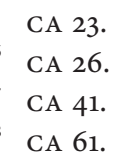


kulturową. Należałoby zatem odnowić pamięć o tym, co tak naprawdę stanęło u podstawy sporu, który wypalając tragiczne piętno na xx stuleciu, ujawnił oszukańcze oblicze uzurpatora. Więcej. Trzeba spytać, czy jego uwalniające odejście oznacza wykluczenie nowych zagrożeń, jakie wyłaniałby się z rezerwuaru tego samego niebezpieczeństwa.

\section{Teoria krytyczna - czym jest?}

Gdy mówimy o teorii krytycznej, należałoby krótko wyjaśnić, w jaki sposób ją rozumiemy, a to oznacza, że warstwa prezentacji powiązana jest $\mathrm{z}$ momentem interpretacyjnym. Już na wstępie pragniemy zwrócić uwagę na trzy sprawy, co pozwoli celniej wyakcentować interesujące nas aspekty badawcze. Po pierwsze, nie chodzi nam o kolejne przypomnienie historii i postaci związanych z powstaniem Instytutu Badań Społecznych we Frankfurcie (1923), co następnie płynnie ewoluowało w stronę szkoły frankfurckiej (zwłaszcza od przejęcia kierownictwa Instytutu przez Maxa Horkheimera w 1931 roku), lecz o wyakcentowanie tych elementów ideowych oraz poznawczych, które wkraczają w bezpośredni obieg namysłu krytycznego, jaki został ukształtowany w tym kręgu intelektualnym i jednocześnie znajdującym częściowe odbicia w refleksjach zawartych w Centesimus annus. Po drugie, wprowadzony ślad związany z Habermasem, uznawanym za jednego z czołowych reprezentantów szkoły (drugiego pokolenia), nie powinien nas zmylić, sugerując, iż pragniemy go uczynić centralnym interlokutorem rozmowy. Owszem, autor Teorii działania komunikacyjnego jest najlepiej rozpoznawalnym i najbardziej wpływowym myślicielem powiązanym z tym środowiskiem, co znajduje potwierdzenie w licznych opracowaniach ${ }^{9}$. Obserwując zresztą ewolucję poglądową, jaką przechodziła i wciąż przechodzi jego myśl, odnosi się wrażenie, że coraz bardziej pulsuje ona autonomicznym życiem intelektualnym, choć z zachowaniem ewolucyjnej ciągłości z ogólniejszymi intencjami badawczymi towarzyszącymi szkole frankfurckiej ${ }^{10}$. Po trzecie

\footnotetext{
9 W literaturze polskiej na uwagę zasługują opracowania Stanisława Czerniaka, Rafała Michalskiego, a zwłaszcza Andrzeja Szahaja. Pionierskie pozostają studia Martina Jaya, Thomasa McCarty'ego, Raymonda Geussa, Rolfa Wiggershausa czy Petera V. Zima.

${ }^{10}$ Postępującą autonomizację Habermasa względem myśli Marksa, neomarksizmu czy nawet programu samej szkoły frankfurckiej dostrzegano już od lat 70., także w kręgach
} 
wreszcie, osoba i twórczość Habermasa są o tyle interesujące, że mogą stanowić punkt orientacyjny dla porządkowania nowej kartografii wobec radykalnych przeobrażeń, jakim współcześnie podlega teoria krytyczna. Choć zrodziła się we wczesnych latach 30. ubiegłego wieku, to jej wspólczesna konotacja, ba, można powiedzieć - początek swoistej mody, datuje się na lata 6o. xx wieku i zbiega się z publikacją pierwszych dojrzałych prac Habermasa ${ }^{11}$. Od tego czasu jednak pojawiło się zjawisko daleko posuniętych przemieszczeń językowo-przedmiotowych, tak że w pewnych obszarach badawczych, nie bez wpływu poststrukturalizmu czy dekonstrukcjonizmu, teoria krytyczna zaczęła funkcjonować niezależnie. Chodzi tu zwłaszcza o amerykańskie „teorie krytycyzmu” związane ze zwrotem językowo-tekstualnym (linguistic turn), gdzie operuje się w obszarze teorii literatury, krytyki literackiej, studiów kulturowych czy egzegezy biblijnej ${ }^{12}$. Świadomy tych zmian Raymond A. Morrow mówił o adaptacjach i koneksjach szkoły frankfurckiej ze współczesnymi ujęciami teorii krytycznej, choć porządkował je według kryteriów językowo-narodowych przynależności (niemiecka, francusko-kanadyjska, anglo-amerykańska $)^{13}$. W rezultacie powiedzielibyśmy, iż aktualna mapa autorów czy problemów odwołujących się do teorii krytycznej zaciera ścisłe przynależności. Samo określenie, jak niezwykle celnie to ujęto, stało się ofiarą swojego niebywałego sukcesu, w wyniku czego wzmacniają się tendencje prowadzące do utraty jego tożsamości ${ }^{14}$. Nie dziwi zatem, że współcześnie coraz częściej pojawiają się dyskusje, czy teoria krytyczna, która wcześniej niemalże identyfikowała się z działaniami szkoły frankfurckiej, nie dokonała skoku emancypacyjnego i w znacznym stopniu nie oderwała się już od zależności od wcześniejszego patronatu.

zbliżonych do marksizmu, np. A. Malinowski, Współczesny „neomarksizm”, Warszawa 1983, s. $182-188$.

${ }^{11}$ W przekonaniu Ricka Rodericka należy mówić o habermasowskim projekcie „rekonstrukcji teorii krytycznej" (R. Roderick, Habermas and the foundations of critical theory, New York 1986, s. 62 n.).

${ }^{12}$ Charakterystyczne jest na przykład, że w niektórych opracowaniach odwołujących się do teorii krytycznej brak jakichkolwiek nawiązań do szkoły frankfurckiej lub są one szczątkowe, np. Critical theory now, ed. Ph. Wexler, New York 1991; L. Tyson, Critical theory today. A user-friendly guide, New York 2006.

${ }_{13}$ R. A. Morrow, D. D. Brown, Critical theory and methodology, London 1994, s. 16-21.

${ }^{14}$ Tak pisze we wstępie do popularnego opracowania Stephen E. Bronner, Critical theory. A very short introduction, New York 2011, s. 8. 
Jeśli wiążemy teorię krytyczną z dokonaniami szkoły frankfurckiej, to w jej aplikacji do „krytycznej teorii społeczeństwa”, jak dookreśla ten aspekt Andrzej Szahaj ${ }^{15}$. Przy wszystkich trudnościach identyfikacyjnych, na jakie wskazuje zdecydowana większość autorów zajmujących się teorią krytyczną, również w kontekście jej rozumienia oraz uprawiania wśród myślicieli, którzy w zróżnicowany sposób orbitują wokół oddziaływania szkoły, ten społeczny komponent dobrze współbrzmi z intencjami towarzyszącymi Centesimus annus, która wpisuje się przecież w ciągłość społecznego nauczania Kościoła oraz samych papieży. Drugim faktorem, który w tym społeczno-filozoficznym kontekście motywuje do przeprowadzenia porównawczego pomostu, jest marksizm lub raczej problem stosunku do marksizmu. Dość jednoznaczne stanowisko oficjalnego nauczania Kościoła ${ }^{16}$ potwierdzone w Centesimus annus mocno kontrastuje $\mathrm{z}$ ideowymi inspiracjami szkoły frankfurckiej. Jest to środowisko, które od swych początków nie kryło, iż szeroko rozumiany marksizm jest istotnym komponentem krytyki społecznej (burżuazyjnego kapitalizmu) oraz remedium na wyjście z ogólniejszego kryzysu, w jakim znalazła się cywilizacja, na której negatywny cień położyły ideologicznie podszyty tryb uprawiania filozofii i nauki oraz polityczny mrok totalitaryzmu. To, że bardziej akcentowano okrucieństwa w jego wersji nazistowskiej niż komunistycznej, może być zrozumiałe przy uwzględnieniu uwarunkowań biograficznych większości członków szkoły, o czym wspominał Leszek Kołakowski, klasyfikując przy tym całą grupę jako ważny, niemiecki ruch o profilu "paramarksistowskim" ${ }^{\prime 1}$.

Faktem jest, że już w pierwszym pokoleniu szkoły ujawnił się, z czasem narastający, dystans wobec jednorodnej interpretacji doktryny marksistowskiej oraz sowieckiego komunizmu, który tę interpretację starał się narzucić. Świadczą o tym zarówno komentarze Horkheimera inspirowane wcześniejszymi badaniami Pollocka ${ }^{18}$, jak i krytyczne oceny dokonań szkoły

${ }^{15}$ A. Szahaj, Teoria krytyczna szkoły frankfurckiej, Warszawa 2008, s. 19.

${ }^{16}$ Z wyjątkiem radykalnych nurtów teologii wyzwolenia czy politycznych zaangażowań w budowanie komunistycznego systemu rządów ze strony działaczy i polityków przyznających się do katolickiej przynależności.

${ }^{17}$ L. Kołakowski, Główne nurty marksizmu. Rozkład, t. 3, Warszawa 2009, s. 342.

${ }_{18}$ Por. M. van der Linden, Western Marxism and the Soviet Union. A survey of critical theories and debates since 1917, trans. J. Bendien, Leiden-Boston 2007, s. 60-63. 
ze strony sowieckiej ${ }^{19}$. Jednocześnie nawiązywano do tekstów Gramsciego, Lukácsa czy Korscha, współtworząc proces kształtowania się „,zachodniego marksizmu" (The Advent of Western Marxism) ${ }^{20}$. Był to podwójny ruch. Zjednej strony dystansowano się wobec ortodoksyjnej, partyjnej wykładni doktryny Marksowskiej czy marksistowskiej, z drugiej natomiast czerpano $\mathrm{z}$ niej podskórne tematy i inspiracje, ceniono aspekty metodologiczne, wykorzystywano instrumenty poznawcze, kształtowano styl myślenia. By pominąć, dyskutowane zresztą, zagadnienie intensywności powyższych powiązań na kolejnych etapach rozwojowych szkoły, co cyrkulowało między marksizmem, neomarksizmem a Nową Lewicą, także uwzględniając osobowe luzowanie tych związków, trudno nie dostrzec, że w większości opracowań „krytyczną teorię społeczeństwa” klasyfikuje się po stronie neomarksistowskiej konfiguracji ideowej. Ocena dokonań szkoły w tym zakresie jest zróżnicowana i nawet, gdy ograniczymy się do polskich komentatorów, natrafimy na całą gamę odniesień i ocen. Odnajdziemy sceptycyzm wobec heterodoksyjnych odchyleń (w starszych opracowaniach: Rainko, Malinowski, Ładosz i odwołujące się do jego dokonań Stowarzyszenie Marksistów Polskich), nadzieje na odnalezienie ożywczych impulsów (środowisko Colloquia Communia i Krytyki Politycznej), oznakę doktrynalnego schyłku i rozpadu (Kołakowski, Walicki) czy przekonanie o teoretycznie najbardziej płodnej interpretacji myśli Marksowskiej (Szahaj).

Nawiązanie do „paramarksistowskiej” proweniencji zostało przywołane ze względu na interesujące nas zagadnienie ideologii, które wyrasta $\mathrm{z}$ bezpośredniej dyskusji nad tezami Marksa i Engelsa zawartymi w Ideologii niemieckiej i już we wczesnej fazie tworzenia się środowiska frankfurckiego wywołało żywe, także redaktorskie, zainteresowanie (Grünberg), a nawet współpracę z sowieckim autorytetem Dawidem Riazanowem ${ }^{21}$. W następnym etapie, już pod wodzą Horkheimera (w dyskusji z Weberem, Mannheimem czy Schelerem) oraz wraz z nastaniem epoki Habermasa krytyka ideologii stała się jedną z oznak krzepnięcia szkoły. Ze spotkanych opracowań wyakcentowanie zagadnienia ideologii najmocniej wybrzmiało w książce Raymonda Geussa, gdzie czyni się z niej klucz do zro-

\footnotetext{
${ }^{19}$ Dictionary of philosophy, ed. I. Frolov, Moscow 1984, s. 149.

${ }^{20}$ P. Anderson, Considerations on Western Marxism, London 1989, s. 24-48.

${ }^{21}$ Por. T. Carver, D. Blank, A political history of the editions of Marx and Engels's "German Ideology Manuscripts", New York 2014, s. 14.
} 
zumienia ciągłości generacyjnej szkoły ${ }^{22}$. Prezentacja myśli Habermasa (ograniczona do lat 7o. ubiegłego wieku) zbiega się z rozpowszechnieniem pojęcia teorii krytycznej. Mając za podstawę prace Marksa oraz nowe lektury (psychoanaliza, fenomenologia, hermeneutyka), czołowi reprezentanci szkoły przeprowadzają autorskie interpretacje, które jednakowoż zdają się podporządkowane wspólnemu celowi: krytyce społecznej.

\section{Krytyka ideologii I}

Analiza zagadnienia ideologii w Centesimus annus oraz teorii krytycznej pokazuje, że w obu przypadkach mamy do czynienia z instancją krytyczno-polemiczną, która jednakowoż operuje w polu dwóch odrębnych podejść metodologicznych wraz z ich teoretycznymi uzasadnieniami oraz praktycznymi konsekwencjami. We wstępnej diagnozie powiedzielibyśmy, iż w przypadku nauczania papieskiego jest to podejście domknięte, metafizykujące, gdzie ideologia posiada ściśle określony oraz niezmienny status poznawczy, podczas gdy teoria krytyczna, wraz z wewnętrzną ewolucją poglądową, jakiej ulegała szkoła, odnosi się do ideologii w perspektywie otwartej, zmiennej, dialektycznej.

Jest charakterystyczne, iż określenie „ideologia” powraca w papieskim dokumencie dość regularnie, a opisywane przez nie zjawisko wywołuje jednostronnie negatywne konsekwencje, zapisuje się zdecydowanie pejoratywną konotacją oraz zasługuje na jednoznacznie ujemną ocenę. Jest to typ myślenia, który u swych podstaw zawiera fałsz, a jest on na tyle głęboki, że zatruwa prawdę o świecie i samym człowieku w każdej relacji, w jaką ten wchodzi. Ideologiczne zakłamanie jest na tyle trwałe, że nie usuwa go doktrynalne wymieszanie, gdzie część twierdzeń daje się uzasadnić czy nawet jest zgodna z elementami chrześcijańskiej nauki społecznej ${ }^{23}$. Jak już wspomnieliśmy, wydarzenia związane z rokiem 1989 są historycznym zapisem politycznego fiaska marksistowsko-leninowskiej odpowiedzi na „kwestię robotniczą”. Ale pojęciem, które tak samo celnie sumowałoby fakt równie spóźnionej, co zapowiadanej klęski, jest ideologiczna natura socjalistycznych odpowiedzi, co „samej

\footnotetext{
${ }^{22}$ R. Geuss, The idea of a critical theory. Habermas and the Frankfurt School, Cambridge 1981, S. 1-3.

23 CA 20.
} 
klasie robotników przyniesie w rezultacie szkodę", jak przewidująco pisał Leon XIII ${ }^{24}$. W Przekroczyć próg nadziei powtórzy się też za Leonem XIII profetyczne ostrzeżenie przed aplikacją komunistycznego lekarstwa, które okazało się groźniejsze od choroby ${ }^{25}$. W wymiarze fenomenalnym przejawy upadku ujawniły się w buncie robotników wobec uzurpacji deklaratywnie „robotniczej władzy”, w ekonomicznym kryzysie, technologicznym spóźnieniu, społecznej anomii, moralnej degrengoladzie. Nie był to jednak efekt odejścia od pierwotnie poprawnie sformułowanej diagnozy wyjaśniającej źródła „robotniczej biedy”, co w komunistycznym żargonie wiązano z „okresami błędów i wypaczeń”. Skazane na porażkę były także próby korekt dokonywane w ramach oczyszczeń kadrowych, a nawet dopuszczenie do głosu pojawiających się postulatów rewizji doktrynalnych, co wcześniej skazywało na anatemę „,rewizjonistycznych odchyleń". Doktryna marksizmu i leninizmu wraz z jej inkarnacją w postaci systemu politycznego ujawniły ideologiczną skazę, którą skrywały od swego początku. Błąd był immanentny i znajdował się wewnątrz komunistycznej odpowiedzi ${ }^{26}$. Po stu latach, odmierzonych czasem między obu encyklikami, nastąpiło przebudzenie robotników, którzy obnażyli kłamstwo systemu zbudowanego na zawłaszczeniach, pozbawili „ideologię prawomocności”27. Marksizm i leninizm oraz motywowane nimi polityczne praxis od swej genezy nie były poznaniem czy wiedzą, lecz ideologią, a ideologia nie była, nie jest i nigdy nie może być solidną odpowiedzią na żadne pytania, które stawia człowiek. Ten typ myślenia jest szkodliwy także wtedy, gdy zawiera w sobie wymieszane elementy, z których część daje się uzasadnić czy nawet jest zgodna z elementami chrześcijańskiej nauki społecznej ${ }^{28}$. O ile jeszcze xIX-wieczny, prekapitalistyczny kontekst powstania „kwestii robotniczej” był autentyczny i uzasadniony, to słuszny sprzeciw został skanalizowany przez ideologię, a ta politycznie zawłaszczyła racje tego sprzeciwu. Tak pisał papież w, niepozbawionej osobistych refleksji, książce-wywiadzie Przekroczyć próg nadziei $i^{29}$.

\footnotetext{
${ }^{24} \mathrm{RN} 3$.

${ }^{25}$ Jan Paweł II, Przekroczyć próg nadziei, Lublin 1994, s. 109.

${ }^{26}$ Tamże.

${ }^{27}$ CA 23

${ }^{28}$ CA 20.

${ }^{29}$ Jan Paweł II, Przekroczyć próg nadziei, s. 108.
} 
Wyraziste przekonania papieża, zwłaszcza na tle bardziej zniuansowanego podejścia wyrażanego już nie tylko ze strony reprezentantów „teorii krytycznej”, lecz także autorów powiązanych z nauczaniem chrześcijańskim $^{30}$, zachęcają do bliższego przyjrzenia się intelektualnym źródłom, z jakich czerpie papieskie myślenie. Powiedzmy wprost, nie pytamy, czy w ogóle, lecz na ile za tym typem spojrzenia badawczego kryje się biogram intelektualny Wojtyły. Chodzi o biogram naznaczony dramatycznym losem człowieka zza „żelaznej kurtyny”, który znał komunizm "od wewnątrz", oraz chrześcijańskiego myśliciela, którego formacja intelektualna kształtowała się w kręgu klasycznego pojmowania filozofii i jej metodologii, szerzej oddychała klasyczną kulturą filozoficzną. Zupełnie naturalnie podkreśla się, iż „badania nad pontyfikatem Jana Pawła II nie mogą zatem nie brać pod uwagę poglądów naukowych i faktów z życia naukowego Karola Wojtyły z okresu krakowsko-lubelskiego"31. Istotnie, wczesny trop formacyjny prowadzi do studiów teologicznych na Wydziale Teologii Uniwersytetu Jagiellońskiego (także późniejszego kontaktu $\mathrm{z}$ krakowskimi kręgami intelektualnymi), ale decydujące znaczenie miało jednak spotkanie z filozofami na Katolickim Uniwersytecie Lubelskim. Twórczo współtworzy przyszły papież odrębną, „lubelską szkołę filozoficzną", a jednocześnie ukuwa własne, dojrzałe poglądy filozoficzne. Nie jest konieczne powtarzanie tego, co o ścisłych związkach Wojtyły z Lublinem już powiedziano ${ }^{32}$. Podkreślmy jedynie, że w szkole lubelskiej szczególne miejsce przydzielano realistycznie zorientowanej metafizyce rozumianej jako filozofia pierwsza. Metafizyka była kluczem do rozwijania poszczególnych dyscyplin poznania filozoficznego, a także probierzem do oceny filozoficznych rozwiązań czy trybem odniesienia do innych dziedzin wiedzy. O ile więc historia filozofii odsłaniała zróżnicowane odniesienia do realistycznie ujętego bytu, wobec czego

${ }^{30} \mathrm{~Np}$. wspomniany Metz wyodrębnił ideologie „pierwszego stopnia”, które oznaczają fałszywe poznanie i pokrywają się z krytyką przeprowadzoną w Centesimus annus, oraz ideologie „drugiego stopnia”, zawierające obiektywne elementy krytyki i postulaty zmiany społeczno-politycznej. J. B. Metz, Religia chrześcijańska a praktyka społeczna, w: Droga do dialogu, Londyn 1970, s. $171 \mathrm{n}$.

${ }^{31}$ H. Juros, Nauka, polityka naukowa i ludzie nauki w życiu Karola Wojtyły. Przyczynek do biografii naukowej Profesora i Papieża, „Nauka” 3 (2005), s. 15.

${ }^{32}$ Obecność. Dar i odpowiedzialność. Karol Wojtyła - Jan Paweł II w Katolickim Uniwersytecie Lubelskim, red. M. Filipiak, A. Szostek, Lublin 2008. 
filozofom z Lublina było bliżej lub dalej do zaproponowanych rozwiązań, o tyle ideologia sytuowała się poza obszarem wiedzy wartościowej, sensu stricto filozoficznej. Jak podkreślał Mieczysław A. Krąpiec, czołowy reprezentant szkoły, filozofia miała chronić myślenie, człowieka i kulturę „W dobie ścierania się rozmaitych kultur, ideologii i wierzeń”, zacierania granic między nauką, wiarą i ideologią̧

Nie ulega wątpliwości, że nieufność kierowana w stronę poznawczych walorów ideologii została wzmocniona polskim kontekstem sporów z marksizmem. Wojtyła jest jego uczestnikiem i jednocześnie świadkiem. Wie, że ze względu na uniwersalne roszczenia doktryny marksistowskiej nie jest to jedynie spór regionalny, lecz nabywa on cech globalnych. Lokowanie i tryb rozwojowy marksizmu w Polsce to poglądowa lekcja dominacji ideologii nad filozofią. Filozofia przestała być sztuką myślenia, a stała się zakładnikiem doktrynalnej pułapki oraz pseudo-poznawczym narzędziem używanym w celu realizacji interesów partii komunistycznej34. Postępujące zjawisko marksistowsko-leninowskiego panowania nad kolejnymi obszarami życia społecznego oraz kultury coraz dobitniej ukazywało, że filozofia wytraca funkcję krytyczną, choć marksiści uważali, że podtrzymują tę funkcję w najbardziej postępowej postaci. To, co Leszek Kołakowski dostrzeże po kilku dekadach poszukiwań, a co będzie efektem osobistych rozczarowań i intelektualnego trudu, Wojtyła i bliskie mu środowisko filozoficzne odczytywało z wnętrza klasycznej kultury filozoficznej, z namysłu nad rzeczywistością świata i człowieka, jaką przynosiła realistycznie zorientowana metafizyka. Warto przy tej okazji podkreślić, iż pewność co do ideologicznych zafałszowań marksizmu nie jest dyktowana jedynie zakorzenieniem w metafizycznym punkcie widzenia czy wynikiem apologii płynącym z chrześcijańskiego nauczania, z którymi marksizm podjął przecież bezpardonową walkę. Analogiczne patrzenie na ideologiczne zaślepienie adeptów „nowej wiary” odnajdziemy wśród znaczących przedstawicieli szkoły lwowsko-warszawskiej, która przecież via Stefan Świeżawski musiała wybrzmieć w kształtowaniu się programu szkoły lubelskiej. Co ciekawe, Wojtyła, w bardziej osobistej formie,

${ }_{33}$ M. A. Krąpiec, Człowiek - kultura - uniwersytet, Lublin 1998, s. 235.

${ }^{34}$ Ciekawa praca powstała w kręgu inspiracyjnym Józefa Bocheńskiego - Z. A. Jordan, Philosophy and ideology. The development of philosophy and Marxism-Leninism in Poland since the second world war, Dordrecht 1963. 
wspomina przebieg polskiego sporu między filozofią a ideologiczną skazą marksizmu, odwołując się właśnie do przykładu reprezentantów szkoły lwowsko-warszawskiej ${ }^{35}$, i krytyczna ocena o przesunięciu idei istotnych dla marksizmu „poza granice nauki” zostaje w tym względzie jedynie potwierdzona przez kompetentnych badaczy tej szkoły ${ }^{36}$. W podobnym tonie wypowiadała się Hannah Arendt. Uważała ona, iż ideologiczna dewiacja, choć ujawniła się w systemach totalitarnych, to genetycznie wyrastała z nowożytności. Podobna diagnoza nie może nie przywołać uwag papieża o negatywnych skutkach kartezjańskiego zwrotu, który odwrócił logikę priorytetu esse nad $\operatorname{cogitans}^{37}$. Arendt rozszerza swoje refleksje, wzbogacając je analizami z pogranicza socjologii oraz teorii polityki, ale kierunek uzasadnień oraz stawiane konkluzje są niemal identyczne. Autorka mówi o niebezpieczeństwach, jakie płyną z nadania priorytetu ideom, poprzez które świadomość chciałaby arbitralnie „rządzić” światem (jego naturą oraz historią) za pomocą wyznaczania mu nieuchronnych praw. Tak rodzi się totalitarna moc ideologii, których fundamentalna troska koncentruje się wokół zabiegów o utrzymanie immanentnej spójności kolejnych rozumowań z zapoznaniem myślenia o „wspólnym świecie” ${ }^{38}$ czy poszukiwania styku z realną rzeczywistościąą.

\section{Krytyka ideologii II}

Zjawisko ideologii, jej krytyka (Ideologiekritik) pojawia się na każdym z etapów rozwojowych szkoły frankfurckiej, a niektóre z jej elementów składowych stały się uprzywilejowanymi komponentami teorii krytycznej. W samej szkole podejmowano to zagadnienie w zróżnicowanych kontekstach poznawczych oraz podpisywano autorskimi komentarzami, choć da się zrekonstruować cechy wspólne. Po pierwsze, problem ideologii jest bezpośrednio powiązany z krytyczną funkcją filozofii i posiada intersekcje $\mathrm{z}$ ideami marksistowskimi; po drugie, krytyka jest motywowana potrzebą dokonania zmiany społecznej, z czym łączy się postulat

${ }^{35}$ Jan Paweł II, Pamięć i tożsamość, Kraków 2005, s. 17-18.

${ }^{36}$ J. Woleński, Filozoficzna szkoła lwowsko-warszawska, Warszawa 1985, s. 307.

${ }^{37}$ Jan Paweł II, Pamięć i tożsamość, s. 16-17.

${ }^{38}$ H. Arendt, Korzenie totalitaryzmu, t. 2, tłum. M. Szawiel, D.Grinberg, Warszawa 2008, s. $287-291$.

39 Tamże, s. 244. 
(interes) emancypacyjny; po trzecie, proces pracy krytycznej nad ideologią sprawia, iż jej status poznawczo-metodologiczny przybiera postać „ukrytycznionej” formy wiedzy.

Wczesne zarysy tego projektu pojawiły się w kluczowym tekście Horkheimera Teoria tradycyjna a teoria klasyczna z 1937 roku i bazowały na radykalnie opozycyjnym sporze między dotychczasowym trybem wykorzystywania rozumu w procesie zdobywania wiedzy a postawą krytyczną, która miała prowadzić do odnowienia ludzkiej racjonalności i zwrócenia jej kompetencji dla dokonania zmiany kulturowo-społecznej. Zarówno dotychczasowa filozofia, jak i nauka nie dostrzegły, iż działały w ogólniejszym systemie wiedzy, który poprzez mechanizm reprodukcyjny podtrzymywał tradycyjny system wpływów i panowania. Uważając, że zarówno humanistyka, jak i przyrodoznawstwo tworzą "czystą teorię" o świecie i człowieku, ulegano oraz petryfikowano mechanizm uwikłań podtrzymujący status quo. Tradycyjna teoria funkcjonowała, nie dostrzegając społeczno-ideologicznych uwarunkowań poznania, a przez to rozum nie był dla "siebie przejrzysty” oraz powodował, iż ludzie myśleli i działali jako elementy „nierozumnego organizmu” ${ }^{40}$. Moc tej naiwności okazała się na tyle silna, że domaga się podjęcia radykalnych kroków gwarantujących odzyskanie rozumu, bo tylko takie warunkują możliwość dokonania zmiany. Chodzi o przejście przez fazę rewolucyjną, która nie zadowoli się wymianą zainfekowanych fragmentów, ale kulturowej całości. Jedynie taki ruch, ujawniając skryte zależności, unieważni wyznaczone role, jakie zabudowywały ramy dotychczasowego systemu.

Mówiąc o intersekcjach z szeroko rozumianym marksizmem, odnajdziemy elementy bliższe, oddalone oraz heterodoksyjne. Bliskim jest analiza poznania i ocena jego wartości w odniesieniu do uwarunkowań zakorzenionych w życiu społecznym oraz wyjaśnienie rozbieżności poprzez odwołanie się (choć nie zawsze wprost) do kategorii „fałszywej świadomości". Miała w niej tkwić tradycyjna teoria wiedzy wraz z wytworzonym na jej zapleczu systemem porządkującym rzeczywistość, zwłaszcza w wymiarze społecznym. Dotychczasowa wiedza, tryb jej zdobywania to nieświadoma siebie samej ideologia dlatego, że nie operuje w pełni władzą rozumu. Oddalona od marksizmu wydaje się być odnowiona koncepcja

\footnotetext{
${ }^{40}$ M. Horkheimer, Teoria tradycyjna a teoria krytyczna, tłum. J. Łoziński, „Colloquia Communia" 2 (1983), s. 48.
} 
racjonalności. Krytyczny model ratio przywołuje na patrona bardziej postać Kartezjusza (autonomia poznania) czy Kanta (świadomość immanentnych uwarunkowań poznania) niż Marksa, ale zdecydowanie bliżej tego ostatniego sytuuje się podana recepta na wyjście z zapaści poprzez radykalne, niemalże rewolucyjne odrzucenie przeszłości. Zbieżności dostrzeżemy w stosowaniu materialistycznej oraz ateistycznej metodologii, gdyż możemy polegać jedynie na „siłach ludzkich” pozbawionych iluzji wsparcia $\mathrm{w}$,ideach niezależnych od niego" ${ }^{41}$ oraz odrzucić metafizyczną, religijną wiarę, głoszącą zależność człowieka „od bytu, który trzeba odkryć" ${ }^{22}$. Akcentem heterodoksyjnym zapisuje się natomiast pomniejszenie roli proletariatu jako grupy społecznie predystynowanej do poznawczego odkrycia ideologicznych zafałszowań oraz wskazanej do realizacji zadania przeprowadzenia zmiany ${ }^{43}$. W tym sensie doktryna Marksa, zachowując wyróżnione miejsce w praktyce krytycznego myślenia, sama podlegała regułom krytyki, tracąc pozycję wyłącznego autorytetu czy wręcz rozstrzygającego arbitra.

Drugi po diagnozie, prognostyczny wymiar teorii krytycznej deklarował „walkę" z tym, co zastane, zgodnie ze wskazówkami „określonymi przez samą teorię" ${ }^{44}$. Chodzi więc o przeprowadzenie głębokiej, kulturowej zmiany, gdzie zagwarantowane panowanie rozumu prowadziłoby do takiego ukształtowania życia społecznego, by rozwijało się harmonijnie. W tym sensie krytyka ideologii rozumianej jako rekonstrukcja ukrytych przedzałożeń myślenia (epistemologicznych, społeczno-politycznych, religijnych) jest etapem wstępnym oraz warunkiem koniecznym dla wyzwolenia rozumu i człowieka. Dopiero wtedy, gdy rozpoznamy interesy, jakie skrywa ideologia, można przystąpić do działań emancypacyjnych. A ich logika, jak życzyłby sobie Habermas, miałaby prowadzić ku osiągnięciu ideału autonomii oraz odpowiedzialności ${ }^{45}$. Nawiasem mówiąc, ten rys emancypacyjny w formie ukrytej i nie zawsze danej wprost pojawia się u wszystkich autorów związanych ze szkołą, natomiast szersze

\footnotetext{
${ }^{41}$ Tenże, Społeczna funkcja filozofii, tłum. J. Doktór, Warszawa 1987, s. 73.

${ }_{42}$ Tenże, Teoria tradycyjna a teoria krytyczna, s. 43.

${ }^{43}$ Tamże, s. 50.

${ }_{44}$ Tamże, s. 57.

${ }^{45}$ J. Habermas, Knowledge and human interesents, trans. J. J. Shapiro, Boston 1973, s. 205-206.
} 
pole teoretycznego namysłu zyskał w twórczości Habermasa ${ }^{46}$. Przy tej okazji warto dodać, że powyższy motyw na trwałe wkomponował się w szerzej rozumianą teorię krytyczną.

Ujawnia się tu wpływ lektury Freuda i zupełnie zasadnie Paul Ricoeur doszukiwał się paraleli między projektem wyzwolenia, jaką krytyczna socjologia proponowała społeczeństwu, a psychoanalizą, która przeprowadza identyczny proces $w$ jednostce ${ }^{47}$. Człowiek świadomy zniewalających sił tkwiących w tradycyjnych formach wiedzy, dominujących formacjach kulturowych, rozwiązaniach prawno-instytucjonalnych, układach społecznych opartych o opresję może dążyć do budowania racjonalnego społeczeństwa eliminującego zagrożenia oraz poszerzającego sferę wolnościową. Tak więc negatywna strona wyzwolenia łączyła się z koniecznością porzucenia ideologii, jaką podtrzymywała tradycyjna teoria, natomiast strona pozytywna oddychała postulatem (interesem) emancypacyjnym. Krytyczne praxis odchodzi od marksowskiej teorii klas i zostaje poszerzone o każdą grupę, która w oparciu o rozum będzie zainteresowana obroną naturalnych potrzeb, wyjściem ze stanu alienacji czy wyobcowania oraz okaże gotowość podjęcia walki z niesprawiedliwością w imię lepszego świata. To prawda, że społeczno-polityczna przyszłość kreślona przez Horkheimera, Habermasa, Adorno i praktykowana przez najbardziej zaangażowanego politycznie Marcusego nigdy nie przybrała skończonej doktrynalnie postaci, choć zgłaszane idee i postulaty odnajdywały szczególnie otwartą recepcję $\mathrm{w}$ środowiskach powiązanych $\mathrm{z}$ lewą i radykalnie lewą stroną sceny politycznej. Nie oznacza to oczywiście, iż prowadzone badania były szczególnie adresowane do tych środowisk i należałoby raczej mówić o spięciu między zbieżnością pewnych idei a selektywnym charakterem lektury.

Trzeci kontekst dyskusji wokół ideologii związany jest ze statusem poznawczo-metodologicznym, jaki jej przydzielano. W tym względzie trzeba mówić o dynamice przeobrażeniowej, jakim podlegały badania prowadzone przez frankfurtczyków, a jej efekty przeniosą się na trwałe

${ }^{46}$ Por. A. Szahaj, Krytyka, emancypacja, dialog. Jürgen Habermas w poszukiwaniu nowego paradygmatu teorii krytycznej, Warszawa 1990; J. Alway, Critical theory and political possibilities. Conceptions of emancipatory politics in the works of Horkheimer, Adorno, Marcuse, and Habermas, London 1995; A. Karalus, Zagadnienie ideologii we wczesnych pismach Jürgena Habermasa, „Idea” 25 (2013), s. 181-198.

47 P. Ricoeur, L'idéologie et l'utopie, Paris 1997, s. 24. 
do nowszych ujęć teorii krytycznej. Możemy pokusić się o wyodrębnienie czterech typów odniesień: negatywnego, opisowego, pozytywnego oraz hyperpozytywnego. Na wczesnym etapie, datowanym na lata 20 . i 30. $\mathrm{xx}$ wieku, mamy do czynienia $\mathrm{z}$ negatywną oceną ideologii, pokrewną $\mathrm{z}$ interpretacją marksistowską. Wskazuje na to dychotomiczny podział na wiedzę pewną i wolną od ideologicznych wpływów oraz na ideologiczną właśnie, gdyż nie jest świadoma swych systemowych uwarunkowań oraz społecznych zależności. Taki typ iluzyjnej wiedzy przypomina Marksowską „fałszywą świadomość”. Jednocześnie krytyczne funkcje rozumu przenoszono również na doktrynę marksistowską, przez co wytracała ona uprzywilejowaną czy nawet wyłączną pozycję rozstrzygającą, choć dwuczłonowy, dysjunktywny podział pozostawał aktualny.

Zasygnalizowany proces dostrzegania braków kompetencyjnych w doktrynie marksistowskiej połączony z poszerzeniem filozoficznych lektur (Freud, Nietzsche) wyznacza drugi tryb podejścia do zjawiska ideologii w szkole frankfurckiej. Jego ślady odnajdziemy w tekstach emigracyjnych $z$ lat 40. i 50. xx wieku, a orbituje on wokół nadania jej bardziej opisowego, neutralnego statusu. Dobrym przykładem dokonującej się ewolucji są komentarze umieszczone w Dialektyce oświecenia. Już tytuł książki wskazuje na istnienie dialektycznego procesu, gdzie oświecenie jako siła emancypacyjna $\mathrm{w}$ trakcie swego rozwoju przekształciło się we własne przeciwieństwo, czego negatywnym skutkiem okazała się postępująca reifikacja podmiotu oraz społeczeństwa. Połączenie idei postępu i rozumności (postęp myśli jako synonim oświecenia ${ }^{48}$ ) żywiło się obietnicą wyzwolenia z lęków przed siłami natury oraz od autorytetu i błędnych wyobrażeń tak, by sprzyjać ludzkiej autonomii oraz wolności. Istotnie, podbój przyrody wzmocnił rozumną podmiotowość, która jednakowoż sama zaczęła ulegać mechanizmowi podboju. Wprowadzony mechanizm emancypacyjny obrócił się przeciwko człowiekowi, gdyż zaczynając od kontroli przyrody, doprowadził do ujarzmienia jego samego. Próba wyprowadzenia człowieka z mitu w imię osiągnięcia dorosłości wybudziła ich stare prawzory oraz nowsze wersje. Podobny paradoks wynikał z "mitycznej zgrozy oświecenia na mit”49. Nieprzypadkowo

${ }^{48}$ M. Horkheimer, T. W. Adorno, Dialektyka oświecenia. Fragmenty filozoficzne, tłum. M. Łukasiewicz, Warszawa 1994, s. 19.

49 Tamże, s. 45. 
przewodnikiem po meandrach europejskiej kultury przestaje być Marks, a jego miejsce zajmuje Nietzsche.

Walka $\mathrm{z}$ ideologią jako fałszywym obrazem świata wprowadziła elementy tego zafałszowania w pracę rozumu. Siła oporu, jaki ideologia wykazała w konfrontacji z oświeceniem, wynikała przecież z uczestnictwa w „myśleniu w ogóle”, a swój ideologiczny aspekt odsłania jedynie w tym, że nigdy nie wywiązuje się ze złożonych obietnic ${ }^{50}$. Dlatego krytyka nie może dalej opierać się o dychotomię prawdziwej wiedzy odwzorowującej świat oraz jej ideologicznej przesłony, którą rozum ma podejrzeć i zdemaskować. W pierwotny sposób element deformacji czy nawet mistyfikacji jest ściśle powiązany z rzeczywistością i krytyka musi nauczyć się z tym żyć. Nie oznacza to poddania się rozumu poprzez wyrażenie pesymistycznej zgody na stan rzeczy, na który nie jesteśmy w stanie wpłynąć. Krytyczna troska kieruje się w stronę samej racjonalności, jej instrumentalizacji, a funkcje rozumu polegają na kolejnych demaskacjach ,ideologii uprzednio usankcjonowanych" 51 . Dopuszczamy więc w obieg dyskursu pojęcie ideologii, aby opisywać zjawiska, które jej podlegają tak, aby rozum bardziej świadomie bronił się przed jej oddziaływaniem. Sam krytycyzm nie wystarcza, gdyż sam ryzykuje przeobrażenie się w ideologię i stan ten może trwać tak długo, aż nie wejdzie w fazę krytyki ideologii ${ }^{52}$. Już Adorno, nie bez poczucia elitarnej dumy, stosował przecież moment opisowy i krytyczny zarazem do analiz „przemysłu kulturalnego”, w tym zwłaszcza do muzyki popularnej.

W końcu mamy trzeci typ odniesienia do ideologii, który, nie tracąc komponentu otwartego, dialektycznego, nabywa pozytywnych konotacji. W sposób naturalny staje przed nami kolejna generacja szkoły frankfurckiej w osobie Jürgena Habermasa i rzeczywiście wymiar pozytywności daje się u niego uchwycić. W tym względzie trzeba docenić przenikliwość Raymonda Geussa, który wyprzedzając późniejsze dokonania Habermasa w zakresie teorii działania komunikacyjnego, wskazuje na ważność kulturowego oraz społecznego podłoża kształtowania się grupowych światopoglądów, będących podstawą dla zaistnienia takiego działania ${ }^{53}$. Odręb-

50 T. W. Adorno, Dialektyka negatywna, tłum. K. Krzemieniowa, Warszawa 1986, s. 205.

${ }_{51}$ M. Horkheimer, T. W. Adorno, Dialektyka oświecenia. Fragmenty filozoficzne, s. 69-70.

${ }^{52}$ T. W. Adorno, Prisms, trans. S. and Sh. Weber, New York 1997, s. 25.

${ }_{53}$ Por. R. Geuss, The idea of a critical theory..., s. 22-26. 
ne grupy i wspólnoty uczestniczą w komunikacji społecznej dotyczącej społecznej modernizacji i jeśli tylko przestrzegają reguł rozmowy, stają naprzeciw siebie ze zróżnicowanymi ideologiami, które konsolidują ich tożsamość. Wzajemne przenikanie się idei i interesów, ich roszczeniowa wyrażalność nie tylko odzwierciedlają demokratyczny pluralizm, lecz także wzmagają dialog oraz konsolidują instytucje ${ }^{54}$. Habermas buduje teoretyczne i etyczne konstrukcje, by racjonalny typ komunikacji był możliwy do przeprowadzenia i posiadał ogólniejszą legitymizację uwolnioną od sądów wartościujących. Jednocześnie nie zapomina o negatywnych oddziaływaniach ideologii, co ujawnia chociażby tendencja do „technicyzacji” życia publicznego, przerost technokratycznego pośrednika czy pojawienie się zakłóceń komunikacyjnych. W rezultacie Habermas, przy uwzględnieniu komunikacyjnych aplikacji, zdaje się przyjmować rozumienie ideologii, jaką prezentował Adorno. Ideologia jawi się jako nieusuwalny komponent życia społecznego. Pozostaje wciąż rodzajem, jeśli nie fałszywego, to partykularnego opisu świata dokonanego $\mathrm{z}$ regionalnego punktu widzenia. Krytyczna teoria komunikacji mierzy się z zadaniem oczyszczenia (samoograniczenia) ideologii określonej grupy z partykularnych treści-interesów, ale nie unieważnia jej udziału w produkcji wiedzy.

I ostatnie ujęcie - hyperpozytywne. Jego aplikacja stosuje się do nowszych ujęć teorii krytycznej i od razu podkreślmy, iż stawiane tam postulaty (interesy emancypacyjne), choć wynikają i są powiązane z dokonaniami szkoły frankfurckiej z różnych jej etapów twórczych, to nie zawsze wywołałyby jej aprobatę. Następuje zmiana sytuacji pokoleniowej oraz nie mniej znacząca modyfikacja konfiguracji poglądowej, zwłaszcza w kontekście koneksji z krytyką kultury. Przede wszystkim zaznacza się, ujawnione już wcześniej i dostrzeżone przez Szackiego, całkowite porzucenie dywagacji nad „bazą na rzecz nadbudowy”55. Trzeba docenić starania Habermasa, by odnaleźć racjonalną teorię społecznego porozumienia, aczkolwiek, nastawione programowo antymetafizycznie, narażają dyskurs na dopuszczenie przekazów niekryjących ideologicznych zaangażowań. Treść przekazu oraz zakładane cele przestaje się ukrywać, lecz zaczyna z całą mocą je głosić i realizować. Trudności nie wynika-

\footnotetext{
${ }^{54}$ J. Habermas, Teoria działania komunikacyjnego, t. 1: Racjonalność działania a racjonalność społeczna, tłum. A. M. Kaniowski, Warszawa 1999, s. 327 n.

55 J. Szacki, Historia myśli socjologicznej, Warszawa 2002, s. 523.
} 
ją z mechanizmu dopuszczenia do głosu grup prezentujących odrębne interesy emancypacyjne, lecz z braku instancji rozstrzygającej spory tam, gdzie racjonalna komunikacja zawodzi. Nie chodzi już nawet o odwołanie się do kategorii prawdy, bo jej kondycja w świecie bez metafizyki jest krucha i chwiejna, lecz chociażby o oparcie zasadności decyzji o zasadę słuszności. Zawieszenie czy też oddalenie momentu rozwiązania sporu na rzecz samego mechanizmu deliberacyjnego może wywołać napięcie zarysowane na linii wysłuchany i niewysłuchany, dominowany i dominujący. Mimo że u Habermasa pojawia się pragnienie przejścia od zasad regulatywnych ku normatywnym, to bez metafizycznego zakorzenienia zostaniemy zdani na ,jednoczącą moc rozumu”, który realizuje się w praktyce emancypacyjnej ${ }^{56}$. Tym samym neutralny mechanizm rozpoznania racji słucha głosu dominujących ideologii bardziej niż rozumu. A wachlarz żądań, choć niezbyt szeroki, będzie się odwoływać do interesów płci, rasy, klasy społecznej czy właśnie ideologii ${ }^{57}$.

\section{Podsumowanie}

Relacje do ideologii będącej istotnym składnikiem teorii krytycznej, jakie zawiera Centesimus annus, są zróżnicowane. W sensie formalnym można mówić nawet o metodologicznej zbieżności z interpretacjami z pierwszego okresu działania szkoły frankfurckiej wtedy, gdy mamy do czynienia ze sceptycyzmem wobec wartości poznawczej, jaką oferuje ideologia. Patrząc jednak na odrębności treściowych uzasadnień, jakie prezentuje Jan Paweł II, wraz z przypomnieniem ostrzeżeń zawartych już w Rerum novarum, bez trudu dostrzeżemy, iż w kluczowych kwestiach (walka klas, idea rewolucyjna, problem własności prywatnej, materialistyczna ekonomia, ateizm) marksizm okazał się zaślepiony ideologicznie w swych podstawach. W świetle nauczania papieskiego ideologiczny fałsz obejmuje en bloc całą teorię marksistowską, podczas gdy w szkole wciąż podtrzymywano jej momenty heurystyczne, zwłaszcza podejście metodologiczne. Dla Jana Pawła II praktycznym potwierdzeniem „zideologizowania marksizmu”

\footnotetext{
${ }^{56}$ J. Habermas, Filozoficzny dyskurs nowoczesności, tłum. M. Łukasiewicz, Kraków 20oo, s. 81.

57 M. Cooke, Between "objectivism” and "contextualism”. The normative foundations of social philosophy, w: Critical theory after Habermas. Encounters and departures, eds. D. Freundlieb, W. Hudson, J. Rundells, Leiden-Boston 2004, s. 66.
} 
jest klęska politycznego praxis, wyrażona w zmierzchu realnego komunizmu. Nic bardziej od pracowniczego buntu przeciw komunistycznej władzy nie obnażyło mechanizmu zawłaszczenia „kwestii robotniczej”.

Nie będzie też problemu, by odnaleźć podobieństwa przy porównaniu opisowego ujęcia ideologii, tym bardziej że w obu przypadkach łączy się z nim moment krytyczny. O ile jednak moc chrześcijańskiego sceptycyzmu stara się trzymać ideologię na zewnątrz swoich filozoficzno-teologicznych eksplikacji, gdyż nauczanie Ewangelii nie jest „ideologią”, o tyle teoria krytyczna wpuszcza jej komponenty do wewnątrz pracy krytycznej. Pozytywne, a już zwłaszcza hyperpozytywne ujęcia ideologii rozgrywają się przede wszystkim w obszarze kultury, obyczajów oraz życia społecznego i, stosując postulat Horkheimera, radykalnie odrzucają ,tradycyjną krytykę" zbudowaną również na modelu dotychczasowej, biblijno-chrześcijańskiej kultury. Jan Paweł II niezwykle celnie odczytał tendencje ideologiczne późnego kapitalizmu, w ramach którego pojawiają się postulaty dokonania głębokich przeobrażeń w wymiarze kulturowo-obyczajowym. Dzieje się tak, gdy wąskie, lecz wpływowe grupy ideologiczne, realizujące partykularne interesy, roszczą sobie prawo do dominowania nad całością społeczną oraz państwem ${ }^{58}$. Owe zagrożenia są zróżnicowane i zostają w końcowej części encykliki wymienione. Nas interesują te, które znajdują odzwierciedlenie w impulsach płynących z teorii krytycznej. Nieprzypadkowo to kultura i obyczaje zostają objęte szczególną troską papieża. O ile bowiem „kwestia robotnicza” uległa ideologicznemu zawłaszczeniu przez marksizm, o tyle nowe wyzwania, rodzące się z emancypacyjnej retoryki operującej wewnątrz teorii krytycznej, przynoszą ryzyko kulturowych wywłaszczeń. Nie mówi się już w nich o problemie ubóstwa, lecz głosi potrzebę kontynuacji rewolucji obyczajowo-kulturowej. To dlatego papież, wzywając do podtrzymania społecznej wrażliwości na ubogich, zwraca jednocześnie uwagę na niebezpieczeństwa wywłaszczenia człowieka od jego uprawnień podstawowych: od życia, rodziny czy moralnego środowiska, sprzyjającego rozwojowi osobowości ${ }^{59}$. Encyklika jedynie zapowiada oraz zarysowuje pola sporu. Ich przebieg i dalszy rozwój wybrzmi jeszcze nieraz, także wtedy, gdy nie skojarzymy przyczyn postulatów wywłaszczeniowych z ideowymi dziejami teorii krytycznej.

\footnotetext{
${ }^{8}$ CA 46.

59 CA 47.
} 


\section{Bibliografia}

Adorno T. W., Dialektyka negatywna, tłum. i wstęp K. Krzemieniowa, Warszawa 1986.

Adorno T. W., Prisms, trans. S. and Sh. Weber, New York 1997.

Alway J., Critical theory and political possibilities. Conceptions of emancipatory politics in the works of Horkheimer, Adorno, Marcuse, and Habermas, London 1995.

Anderson P., Considerations on Westen Marxism, London 1989.

Arendt H., Korzenie totalitaryzmu, t. 2, tłum. D. Grinberg, M. Szawiel, Warszawa 1989.

Bronner S. E., Critical theory. A very short introduction, New York 2011.

Carver T., Blank D., A political history of the editions of Marx and Engels's „German Ideology Manuscripts”, New York 2014.

Cooke M., Between „objectivism” and „contextualism”. The normative foundations of social philosophy, w: Critical theory after Habermas. Encounters and departures, eds. D. Freundlieb, W. Hudson, J. Rundells, Leiden-Boston 2004.

Critical theory now, ed. Ph. Wexler, New York 1991.

Dictionary of philosophy, ed. I. Frolov, Moscow 1984.

Geuss R., The idea of a critical theory. Habermas and the Frankfurt School, Cambridge 1981.

Habermas and religion, eds. C. Calhoun, E. Mendieta, J. Van Antwerpen, Cambridge 2013 .

Habermas J. i in., An awereness of what is missing. Faith and reason in a postsecular age, trans. C. Cronin, Cambridge 2010.

Habermas J., Filozoficzny dyskurs nowoczesności, tłum. M. Łukasiewicz, Kraków 2000.

Habermas J., Knowledge and human interesents, trans. J. J. Shapiro, Boston 1973.

Habermas J., Teoria działania komunikacyjnego, t. 1: Racjonalność działania a racjonalność społeczna, tłum. A. M. Kaniowski, Warszawa 1999.

Horkheimer M., Adorno T. W., Dialektyka oświecenia. Fragmenty filozoficzne, tłum. M. Łukasiewicz, Warszawa 1994.

Horkheimer M., Społeczna funkcja filozofii, tłum. J. Doktór, Warszawa 1987.

Horkheimer M., Teoria tradycyjna a teoria krytyczna, tłum. J. Łoziński, „Colloquia Communia" 2 (1983), s. 39-64.

Jan Paweł II, Encyklika Centesimus annus, przedruk: Libreria Editrice Vaticana, Włocławek 1991. 
Jan Paweł II, Pamięć i tożsamość, Kraków 2005.

Jan Paweł II, Przekroczyć próg nadziei. Jan Paweł II odpowiada na pytania Vittoria Messoriego, Lublin 1994.

Jordan Z. A., Philosophy and ideology. The development of philosophy and Marxism-Leninism in Poland since the second world war, Dordrecht 1963.

Junker-Kenny M., Habermas and theology, London-New York 2011.

Juros H., Nauka, polityka naukowa i ludzie nauki w życiu Karola Wojtyły. Przyczynek do biografii naukowej Profesora i Papieża, „Nauka” 3 (2005), s. 9-23.

Karalus A., Zagadnienie ideologii we wczesnych pismach Jürgena Habermasa, „Idea” 25 (2013), s. 181-198.

Kołakowski L., Główne nurty marksizmu. Rozkład, t. 3, Warszawa 2009.

Krąpiec M. A., Człowiek - kultura - uniwersytet, Lublin 1998.

Leon XIII, Encyklika Rerum novarum, Te Deum, Warszawa 2001.

Linden M. van der, Western Marxism and the Soviet Union. A survey of critical theories and debates since 1917, trans. J. Bendien, Leiden-Boston 2007.

Malinowski A., Współczesny „neomarksizm”, Warszawa 1983.

Metz J. B., Religia chrześcijańska a praktyka społeczna, w: Droga do dialogu, Londyn 1970, s. 161-176.

Morrow R. A., Brown D. D., Critical theory and methodology, London 1994.

Obecność. Dar i odpowiedzialność. Karol Wojtyła - Jan Paweł II w Katolickim Uniwersytecie Lubelskim, red. M. Filipiak, A. Szostek, Lublin 2008.

Ricoeur P., L'idéologie et l'utopie, Paris 1997.

Roderick R., Habermas and the foundations of critical theory, New York 1986.

Szacki J., Historia myśli socjologicznej, Warszawa 2002.

Szahaj A., Krytyka, emancypacja, dialog. Jürgen Habermas w poszukiwaniu nowego paradygmatu teorii krytycznej, Warszawa 1990.

Szahaj A., Teoria krytyczna szkoły frankfurckiej, Warszawa 2008.

The Frankfurt School on religion. Key writings by the major thinkers, ed. E. Mendieta, London-New York 2005.

Tyson L., Critical theory today. A user-friendly guide, New York 2006.

Woleński J., Filozoficzna szkoła lwowsko-warszawska, Warszawa 1985.

\section{Abstrakt}

W encyklice Centesimus annus Jan Paweł II odnawia pytania postawione przez swego poprzednika Leona XIII. Zasadniczej zmianie uległ społeczno-polityczny kontekst tych pytań, gdyż upadek systemu realnego komunizmu obnażył fałsz, 
jaki znajdował się w marksistowskiej interpretacji „kwestii robotniczej”. Doktryna marksistowska skazana była na porażkę, ponieważ rozpoznanie problemu było zarazem jego ideologicznym zawłaszczeniem. Krytyka ideologii towarzyszy nauczaniu Kościoła i w tym aspekcie pozostaje w zbieżności z teorią krytyczną. To szeroki nurt, którego istotnym etapem formacyjnym była działalność szkoły frankfurckiej. Jej czołowi przedstawiciele wykorzystywali pewne elementy marksizmu oraz reprezentowali dialektyczne podejście do ideologii. Wskazywali na jej poznawcze braki, a jednocześnie wpuszczali w obieg dyskursu filozoficznego. W rezultacie moment krytyczny łączył się z postulatem emancypacyjnym, który coraz bardziej przesuwał się z obszaru życia społecznego na kulturę. W wyniku tych przesunięć ideologia stała się instrumentem dla realizacji idei, które stanowią ryzyko kulturowych wywłaszczeń człowieka.

Ideological appropriation and cultural expropriation. Centesimus annus and the critical theory

\begin{abstract}
The encyclic of John Paul II, Centesimus annus renews questions started by his predecessor Leo xIII. The socio-political context of these questions has changed, since the collapse of the system of real communism exposed the falsehood in the Marxist interpretation of the „worker question”. The Marxist doctrine was doomed to failure because the diagnosis of the problem was also an ideological appropriation. The critic of ideology is accompanied by the teaching of the Church, and in this aspect remains in the convergence of critical theory. This wide movement, which is an essential step in the formation, was the School of Frankfurt. Its leading representatives have used some elements of Marxism and represented the dialectical approach to ideology. They pointed to its cognitive deficiencies while incorporating it into the philosophical discourse. The critical moment was therefore connected with the postulate of emancipation that was increasingly moving from the social area to culture. As a result of these shifts, ideology is an instrument for the implementation of the ideas that present the risk of the cultural expropriation of human beings.
\end{abstract}

